Article

\title{
Epileptiform Neuronal Discharges Impair Astrocyte Syncytial Isopotentiality in Acute Hippocampal Slices
}

\author{
Qi Wang ${ }^{1}$, Wei Wang ${ }^{1,2}$, Sydney Aten ${ }^{1}$, Conrad M. Kiyoshi ${ }^{1}$, Yixing Du ${ }^{1, *}$ and Min Zhou ${ }^{1, *} \mathbb{C}$ \\ 1 Department of Neuroscience, The Ohio State University Wexner Medical Center, Columbus, OH 43210 USA; \\ Qi.Wang@osumc.edu (Q.W.); wwang@hust.edu.cn (W.W.); Aten.19@osu.edu (S.A.); \\ kiyoshi.1@osu.edu (C.M.K.) \\ 2 Department of Physiology, School of Basic Medicine, Tongji Medical College, Huazhong University of \\ Science and Technology, Wuhan 430030, China \\ * Correspondence: du.377@osu.edu (Y.D.); zhou.787@osu.edu (M.Z.); Tel.: +1-614-366-9409 (Y.D.); \\ +1-614-366-9406 (M.Z.)
}

Received: 29 February 2020; Accepted: 31 March 2020; Published: 2 April 2020

\begin{abstract}
Astrocyte syncytial isopotentiality is a physiological mechanism resulting from a strong electrical coupling among astrocytes. We have previously shown that syncytial isopotentiality exists as a system-wide feature that coordinates astrocytes into a system for high efficient regulation of brain homeostasis. Neuronal activity is known to regulate gap junction coupling through alteration of extracellular ions and neurotransmitters. However, the extent to which epileptic neuronal activity impairs the syncytial isopotentiality is unknown. Here, the neuronal epileptiform bursts were induced in acute hippocampal slices by removal of $\mathrm{Mg}^{2+}\left(\mathrm{Mg}^{2+}\right.$ free) from bath solution and inhibition of $\gamma$-aminobutyric acid A $\left(\mathrm{GABA}_{\mathrm{A}}\right)$ receptors by $100 \mu \mathrm{M}$ picrotoxin (PTX). The change in syncytial coupling was monitored by using a $\mathrm{K}^{+}$free- $\mathrm{Na}^{+}$-containing electrode solution $\left(\left[\mathrm{Na}^{+}\right]_{\mathrm{p}}\right)$ in the electrophysiological recording where the substitution of intracellular $\mathrm{K}^{+}$by $\mathrm{Na}^{+}$ions dissipates the physiological membrane potential $\left(\mathrm{V}_{\mathrm{M}}\right)$ to $\sim 0 \mathrm{mV}$ in the recorded astrocyte. However, in a syncytial coupled astrocyte, the $\left[\mathrm{Na}^{+}\right]_{p}$ induced $\mathrm{V}_{\mathrm{M}}$ loss can be compensated by the coupled astrocytes to a quasi-physiological membrane potential of $\sim 73 \mathrm{mV}$. After short-term exposure to this experimental epileptic condition, a significant closure of syncytial coupling was indicated by a shift of the quasi-physiological membrane potential to $-60 \mathrm{mV}$, corresponding to a $90 \%$ reduction of syncytial coupling strength. Consequently, the closure of syncytial coupling significantly decreased the ability of the syncytium for spatial redistribution of $\mathrm{K}^{+}$ions. Altogether, our results show that epileptiform neuronal discharges weaken the strength of syncytial coupling and that in turn impairs the capacity of a syncytium for spatial redistribution of $\mathrm{K}^{+}$ions.
\end{abstract}

Keywords: astrocytes; gap junction; astrocyte syncytial isopotentiality; epilepsy; potassium homeostasis

\section{Introduction}

Astrocytes establish the largest syncytium through gap junction coupling [1-3]. This anatomical attribute permits spatial buffering of $\mathrm{K}^{+}$and $\mathrm{Na}^{+}$ions and long-range redistribution of nutrients, metabolites and signaling molecules that are crucial for neuronal activity, tuning of neuronal oscillations, and brain energy metabolism [4-8]. The importance of this astrocytic network in brain function has been best illustrated in mice deficient in astrocytic gap junction channels connexin 43 (Cx43) and 30 (Cx30); this genetic manipulation resulted in a massively disturbed $\mathrm{K}^{+}$and glutamate homeostasis, interrupted synaptic long-term potentiation (LTP), and impaired sensorimotor and spatial memory tasks [9-12].

The electrolyte-filled gap junctions also serve as electrical conductors that equalize the voltages among coupled cells. Indeed, a strong electrical coupling does confer an isopotentiality to astrocyte 
network across the brain [13-15]. In a demonstrated case, we showed that only under the syncytial isopotentiality, a sustained driving force can be maintained for high efficient $\mathrm{K}^{+}$uptake. This physiological mechanism should also facilitate $\mathrm{Na}^{+}$-dependent uptake systems that are copiously expressed in astrocytes, such as glutamate, GABA and glycine transporters [16].

The pathological relationship between epileptic neuronal activity and astrocytic gap junction coupling remains a matter of debate. For example, the syncytial coupling is speculated to counteract the hyperactivity and synaptic transmission through facilitation of the uptake of neuronal released $\mathrm{K}^{+}$ and glutamate. This view is supported by a gene knockout study; deletion of astrocytic C $433 / \mathrm{C} \times 30$ increased spontaneous epileptiform activity and decreased seizure thresholds [10,12]. However, excessive $\mathrm{Ca}^{2+}$-waves and other intracellular signals in an astrocytic syncytium may synchronize the activity of neurons within the network, and this synaptic transmission independent mechanism could facilitate seizures in an intact astrocyte syncytial network [17,18].

It is possible that in keeping up with the demand for neuronal hyperactivity, epileptic neuronal firing may up-regulate the strength of syncytial coupling and therefore the capacity of astrocyte homeostatic function. On the other hand, excessive neurotransmitter released from firing neurons could also elevate the intracellular $\mathrm{Ca}^{2+}\left(\left[\mathrm{Ca}^{2+}\right]_{\mathrm{i}}\right)$ to pathological levels in astrocytes $[19,20]$, and the latter is known to disrupt gap junctions [21,22]. Nevertheless, which of the above scenarios occurs to the astrocyte network is yet to be determined.

To answer this question, the impact of epileptiform discharges on the coupling strength of astrocyte syncytium is examined with our newly developed electrophysiological method [23]. We show that this experimental epileptic condition severely impairs the coupling strength of hippocampal astrocyte syncytium.

\section{Materials and Methods}

\subsection{Animals}

All of the experimental procedures were performed in accordance with a protocol approved by the Animal Care and Use Committees of The Ohio State University. The wild type C57BL/6J and BAC-ALDH1L1-eGFP transgenic mice of both sexes at postnatal days (P) 21-28 were used in the present study $[15,24,25]$

\subsection{Preparation of Acute Hippocampal Slices and Freshly Dissociated Astrocytes}

Hippocampal slices were prepared from P21-25 mice as we have previously reported [26]. Briefly, in each preparation, a brain was rapidly removed from skull and placed into ice-cold oxygenated ( $95 \% \mathrm{O}_{2} / 5 \% \mathrm{CO}_{2}$ ) slice cutting artificial cerebrospinal fluid (aCSF) with reduced $\mathrm{Ca}^{2+}$ and increased $\mathrm{Mg}^{2+}$ (in mM: $125 \mathrm{NaCl}, 3.5 \mathrm{KCl}, 25 \mathrm{NaHCO}_{3}, 1.25 \mathrm{NaH}_{2} \mathrm{PO}_{4}, 0.1 \mathrm{CaCl}_{2}, 3 \mathrm{MgCl}_{2}$ and 10 glucose). Coronal hippocampal slices (250 $\mu \mathrm{m}$ thickness) were cut at $4{ }^{\circ} \mathrm{C}$ with a Vibratome (Pelco 1500, Ted Pella, Inc., Redding, CA, USA) and transferred to the oxygenated standard aCSF (in mM: $125 \mathrm{NaCl}$, $25 \mathrm{NaHCO}_{3}, 1.25 \mathrm{NaH}_{2} \mathrm{PO}_{4}, 3.5 \mathrm{KCl}, 2 \mathrm{CaCl}_{2}, 1 \mathrm{MgCl}_{2}$ and 10 glucose, osmolality $295 \pm 5 \mathrm{mOsm}$; $\mathrm{pH}$ 7.3-7.4). Brain slices were allowed to recover from preparation damage for at least $1 \mathrm{~h}$ at room temperature before recording. For sulforhodamine 101 (SR101) staining [27], the slices were transferred to a beaker with slice-holding basket containing $0.6 \mu \mathrm{M}$ SR101 in aCSF, and were incubated at $34{ }^{\circ} \mathrm{C}$ for $30 \mathrm{~min}$. Then, the slices were transferred back to standard aCSF at room temperature before recording. In the experiment for manipulating coupling strength, brain slices were pretreated with aCSF containing $100 \mu \mathrm{M}$ meclofenamic acid (MFA) for one hour before recording and perfused with the same solution during recording. To induce epileptiform discharges, brain slices were perfused with $\mathrm{Mg}^{2+}$ free-PTX aCSF (in mM: $125 \mathrm{NaCl}, 25 \mathrm{NaHCO}_{3}, 1.25 \mathrm{NaH}_{2} \mathrm{PO}_{4}, 3.5 \mathrm{KCl}, 2 \mathrm{CaCl}_{2}, 10$ glucose, and $100 \mu \mathrm{M}$ picrotoxin (PTX), osmolality $295 \pm 5$ mOsm; $\mathrm{pH}$ 7.3-7.4).

To prepare freshly dissociated astrocytes, hippocampal brain slices were first incubated for $30 \mathrm{~min}$ in oxygenated aCSF supplemented with $0.6 \mu \mathrm{M}$ SR101 at $34{ }^{\circ} \mathrm{C}$. Then, the CA1 regions were dissected 
out and cut into $\sim 1 \mathrm{~mm}^{3}$ pieces and transferred into a $1.5 \mathrm{~mL}$ Eppendorf tube containing oxygenated aCSF supplemented with $24 \mathrm{U} / \mathrm{mL}$ papain and $0.8 \mathrm{mg} / \mathrm{mL}$ L-cysteine for $7 \mathrm{~min}$ at RT. After papain digestion, the tissues were gently triturated 5-7 times into a cell suspension, which was then transferred into the recording chamber [28,29]. Although the cell suspensions contain tissue blocks varying in the number of astrocytes, only single dissociated astrocytes were used in this study.

\subsection{Electrophysiology}

For brain slice recording, individual hippocampal slices were transferred to a recording chamber (RC-22, Warner Instruments, Holliston, MA, USA) mounted on a BX51WI microscope (Olympus, Olympus American, Inc., Melville, NY, USA) equipped with infrared differential interference (IR-DIC) and were perfused with oxygenated aCSF $(2.5 \mathrm{~mL} / \mathrm{min})$ at room temperature.

Recording pipettes were fabricated from borosilicate capillaries (1.5/0.86 mm outer/inner diameter, Warner Instruments) using a Flaming/Brown Micropipette Puller (Model P-87, Sutter Instrument, Novato, CA, USA). When filled with pipette solution noted below, the pipettes had the open tip

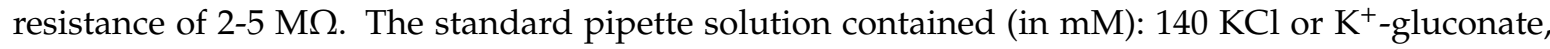
$0.5 \mathrm{CaCl}_{2}, 1 \mathrm{MgCl}_{2}, 5$ EDTA, $10 \mathrm{HEPES}, 3 \mathrm{Mg}$-ATP and $0.3 \mathrm{Na}_{2}$-GTP that was titrated with $\mathrm{KOH}$ to $\mathrm{pH}$ 7.25-7.27. The final osmolality was $280 \mathrm{mOsm}$. In $\mathrm{K}^{+}$free- $\mathrm{Na}^{+}$containing, or $\mathrm{K}^{+}$free-NMDG-Cl containing pipette solutions, the $140 \mathrm{mM} \mathrm{KCl}$ or $\mathrm{K}^{+}$-gluconate in the standard pipette solution was substituted by $140 \mathrm{mM} \mathrm{NaCl}$, or NMDG-Cl, respectively.

Whole-cell patch clamp recordings were performed using a MultiClamp 700A amplifier and pClamp 9.2 software (Molecular Devices, Sunnyvale, CA, USA). A minimum of 2 G $\Omega$ seal resistance was required before rupturing the membrane into whole-cell configuration. The membrane potential $\left(V_{\mathrm{M}}\right)$ was read either in " $\mathrm{I}=0$ " mode or measured directly in current clamp mode without applying any holding currents. For neuronal recording, the access resistance $\left(R_{\mathrm{a}}\right)$, membrane resistance $\left(R_{\mathrm{M}}\right)$, and membrane capacitance $\left(\mathrm{C}_{\mathrm{M}}\right)$ were measured from "Membrane test" protocol built into the pClampex9.2. For quality control, a $R_{\mathrm{a}}<20 \mathrm{M} \Omega$ is used to include neurons into final data analysis. For the low $R_{\mathrm{M}}$ astrocytes, only the membrane input resistance $\left(R_{\mathrm{in}}\right)$ was measured by "Resistance test" protocol in pClampex 9.2 (pulse: $-63 \mathrm{pA} / 600 \mathrm{~ms}$ ), and any recordings with $R_{\text {in }}>50 \mathrm{M} \Omega$ were discarded [30]. All the experiments were conducted at room temperature $\left(20 \pm 2{ }^{\circ} \mathrm{C}\right)$. The liquid junction potential was compensated for before establishment of cell-attached mode and confirmed to be at $\sim 0 \mathrm{mV}$ after experiments by withdrawal of recording pipette.

\subsection{Imaging of Aldh1l1-eGFP Astrocytes and Analysis}

Acute hippocampal slices were prepared from P21-25 BAC-ALDH1L1-eGFP transgenic mice according to the same procedure as for electrophysiological recording. Hippocampal slices obtained were first allowed to recover in aCSF for one hour. Then hippocampal slices were then randomly divided into control (in standard aCSF), and $\mathrm{Mg}^{2+}$ free-PTX groups. After incubation with $\mathrm{Mg}^{2+}$ free-PTX or aCSF for $4.0 \pm 1.0 \mathrm{~h}(n=8-9$ hemisphere brain slices), the slices were quickly washed by aCSF, then were incubated in $4 \%$ paraformaldehyde (PFA) in phosphate-buffered solution (PBS) for $90 \mathrm{~min}$ at room temperature. Tissue sections were then mounted onto microscope slides and were coverslipped with Fluoromount G (SouthernBiotech, SouthernBiotech Company, Birmingham, AL, USA). Z stack images (approximately 20-30 $\mu \mathrm{m}$ in depth) were acquired using an SP8 confocal microscope (Leica, Leica Microsystems Inc., Buffalo Graves, IL, USA). Acquisition parameters were held constant for both control and $\mathrm{Mg}^{2+}$ free-PTX groups.

\subsection{Chemical Reagents}

SR101 was purchased from Invitrogen (New York, NY, USA). All other used chemicals and salts were purchased from Sigma-Aldrich (St. Louis, MO, USA). Meclofenamic acid (MFA) was directly dissolved in aCSF before experiment. $100 \mathrm{mM}$ picrotoxin (PTX) were dissolved in dimethyl sulfoxide 
(DMSO) and stored in a $-20{ }^{\circ} \mathrm{C}$ freezer prior to use. The stock solutions were diluted to the final experimental concentration just before each experiment.

\subsection{Data Analyses}

Image data were analyzed using NIH ImageJ software (Image $1.43 \mathrm{~m}$, National Institutes of Health, Bethesda, MD, USA) and LAS X software (LAS X Small_2.0.0, Leica Microsystems, Buffalo Grave, IL, USA). Other data were analyzed using Origin software (Origin 8.0, OriginLab, Northampton, MA, USA). Data are reported as mean \pm SEM. Shapiro-Wilk test was carried out for normality and F-test was carried out for variance homogeneity. Mean differences between groups were detected using Student's t-test. For data that did not meet the assumptions of normality and homogenous variances, the nonparametric Mann-Whitney U test was used instead. Significance level was set at $p<0.05$.

\section{Results}

\subsection{Induction of Neuronal Epileptiform Discharges in Hippocampal Slices}

To determine how excessive neuronal firing affects syncytial isopotentiality, a modified aCSF with removal of $1 \mathrm{mM} \mathrm{MgCl}$ and addition of $100 \mu \mathrm{M}$ PTX $\left(\mathrm{Mg}^{2+}\right.$ free-PTX solution) was bath perfused to hippocampal slices. To confirm that neuronal epileptiform discharges could be readily induced, membrane potential $\left(V_{\mathrm{M}}\right)$ of hippocampal CA1 pyramidal neurons were recorded. Pyramidal neurons in CA1 region were identified based on distinct morphology and location (Figure 1A). These neurons showed a resting membrane potential $\left(V_{\mathrm{M}}\right)$ of $-61.2 \pm 0.9 \mathrm{mV}(n=15$ recordings from three mice), a membrane resistance $\left(R_{\mathrm{M}}\right)$ of $154.1 \pm 11.2 \mathrm{M} \Omega(\mathrm{n}=10$ recordings from three mice), and a membrane capacitance $\left(\mathrm{C}_{\mathrm{M}}\right)$ of $91.7 \pm 8.9 \mathrm{pF}$ ( $n=10$ recordings from three mice). In voltage-clamp recording, the depolarization steps induced a sequential activation of voltage-gated inward $\mathrm{Na}^{+}\left(\mathrm{IN}_{\mathrm{a}}\right)$, outward transient $\mathrm{K}^{+}$channels $\left(I \mathrm{~K}_{\mathrm{a}}\right)$ and delayed rectifying $\mathrm{K}^{+}$channels $\left(I \mathrm{~K}_{\mathrm{d}}\right)$ (Figure $\left.1 \mathrm{~B}\right)$. These properties were consistent with our previous reports $[29,31,32]$.

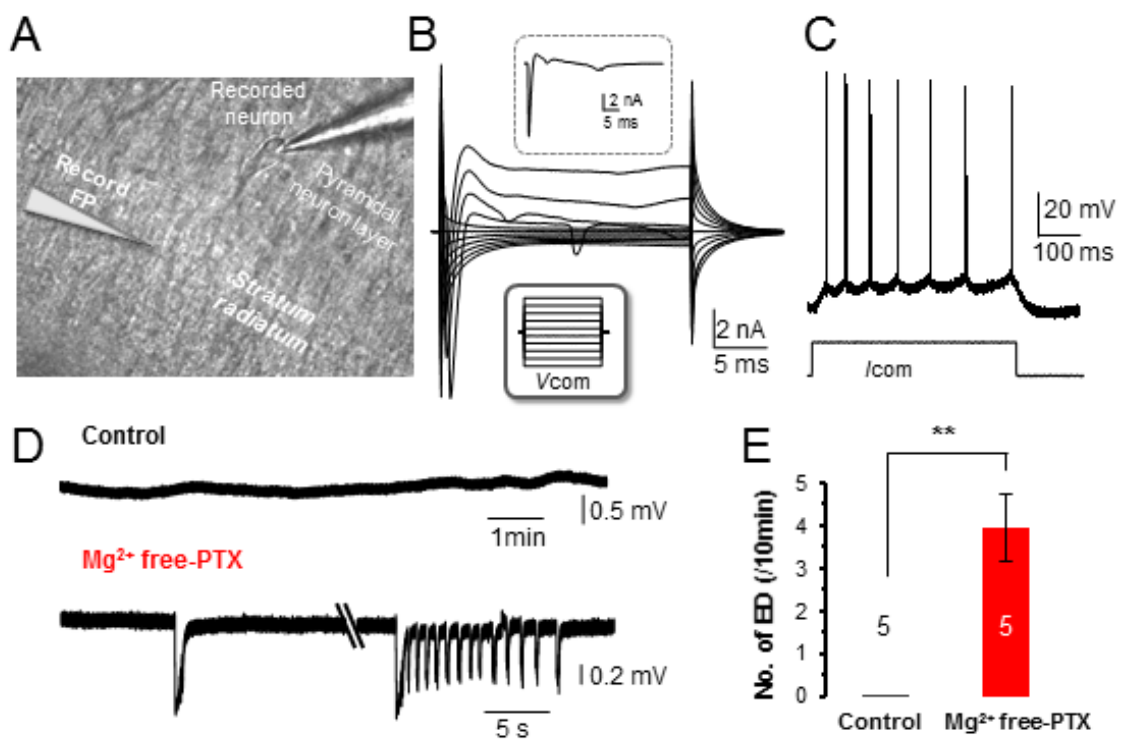

Figure 1. Cont. 
$\mathrm{F}$

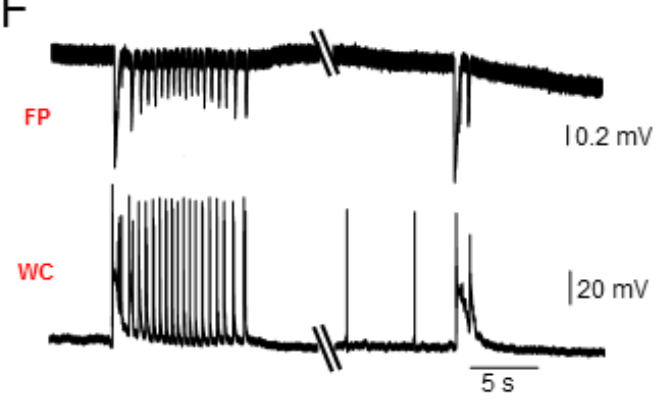

G

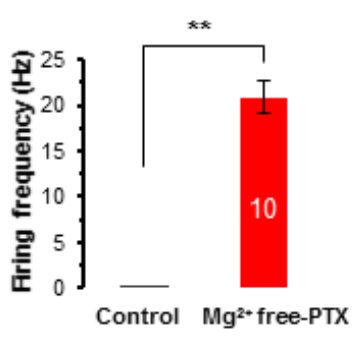

Figure 1. Epileptiform discharges induced by $\mathrm{Mg}^{2+}$ free-PTX. (A) Differential interference contrast (DIC) image of a portion of the CA1 region in an acute hippocampal slice. Pyramidal neurons could be readily identified from the pyramidal neuron layer based on cell morphology. Whole-cell (WC) recording from a pyramidal neuron first in the voltage-clamp (B), then current-clamp (C). (B) In voltage-clamp recording, the pyramidal neuron was held at $-70 \mathrm{mV}$ at resting and then stepped to command voltages $\left(V_{\mathrm{COM}}\right)$ from $-160 \mathrm{mV}$ to $+20 \mathrm{mV}$ at $20 \mathrm{mV}$ increment and $25 \mathrm{~ms}$ duration (lower inset in $\mathbf{B}$ ), and there was a $1 \mathrm{~s}$ interval between the consecutive $V_{\mathrm{COM}}$ steps. The pyramidal neuron was characterized by large depolarization step-activated inward $\mathrm{Na}^{+}$and the following voltage-gated

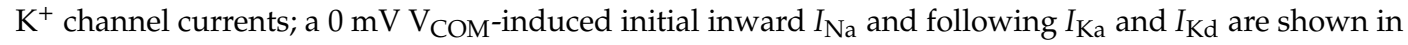
the upper inset in (B,C) In the current-clamp recording, the current injection, $50 \mathrm{pA} / 500 \mathrm{~ms}$ induced multiple action potentials that fired with adaptation. (D) Field potential (FP) recording from stratum radiatum region (lower electrode in $\mathbf{A}$ ), first in control, and then in $\mathrm{Mg}^{2+}$ free-PTX as indicated. Two different forms of epileptiform discharge (ED) are shown. (E) The frequency of ED events in $\mathrm{Mg}^{2+}$ free-PTX compared to control. (F) WC and FP dual recording; high frequency of neuronal firing is temporally phase-locked with ED. (G) High frequency of neuronal firing during ED events compared to non-ED events. ${ }^{* *}: p<0.01$.

In current-clamp recording, the CA1 pyramidal neurons were quiescent at resting conditions. The action potentials could only be induced by positive current injection, and the induced multiple spikes exhibited a characteristic adaptation (Figure 1C) [31,32]. Upon exposure to $\mathrm{Mg}^{2+}$ free-PTX solution, epileptiform discharges (EDs) at variable durations were induced (Figure 1D) at the frequency of $4.0 \pm$ $0.8 / \mathrm{min}(n=5$ recordings from three mice, $p<0.01)$. To further correlate the ED events to the firing of individual neurons, neuronal whole-cell and field potential were simultaneously recorded (Figure 1A). Indeed, the onset of the burst firing of recorded neurons was always phase-locked with the ED events (Figure 1F). The burst neuronal firing reached to a frequency of $20.9 \pm 1.8 \mathrm{~Hz}(n=10 \mathrm{EDs}$ from three mice, $p<0.01)$. Together, we showed that $\mathrm{Mg}^{2+}$ free-PTX treatment indeed induced ED events as a results of synchronized firing of neurons [33]. 3.2. Acute Exposure to $\mathrm{Mg}^{2+}$ Free-PTX Conditions does not Alter the Anatomy of Astrocyte Syncytium

We have previously shown that each astrocyte is directly coupled to 7-9 of the nearest neighbors and this spatial arrangement is a prerequisite for syncytial isopotentiality to be achieved [13-15]. To answer if the $\mathrm{Mg}^{2+}$ free-PTX condition alters the cellular structure and spatial organization of astrocytes, we took advantage of BAC-ALDH1L1-eGFP transgenic mice to visualize astrocytes by their eGFP expression $[14,15,25]$. In acutely prepared brain slices, a feasible time window to examine the impact of the $\mathrm{Mg}^{2+}$ free-PTX conditions on astrocyte anatomy and function is around 2-6 hours. Therefore, the acute hippocampal slices were treated in oxygenated $\mathrm{Mg}^{2+}$ free-PTX solution for $4.0 \pm 1.0$ hours before confocal morphometric analysis (see Methods). At the cellular level, no obvious change in astrocyte morphology was found after treatment with $\mathrm{Mg}^{2+}$ free-PTX i.e., hypertrophy or shrinkage in cell body and processes. At the syncytial network level, astrocyte cell density remained unchanged (Figure 2A,B,E), so was the interastrocyte distance and the number of the nearest neighbors after $\mathrm{Mg}^{2+}$ free-PTX treatment (Figure 2C,D,F,G). Taken together, these results suggest that within the time window of $\mathrm{Mg}^{2+}$ free-PTX treatment, the anatomy of astrocytes remains intact. 

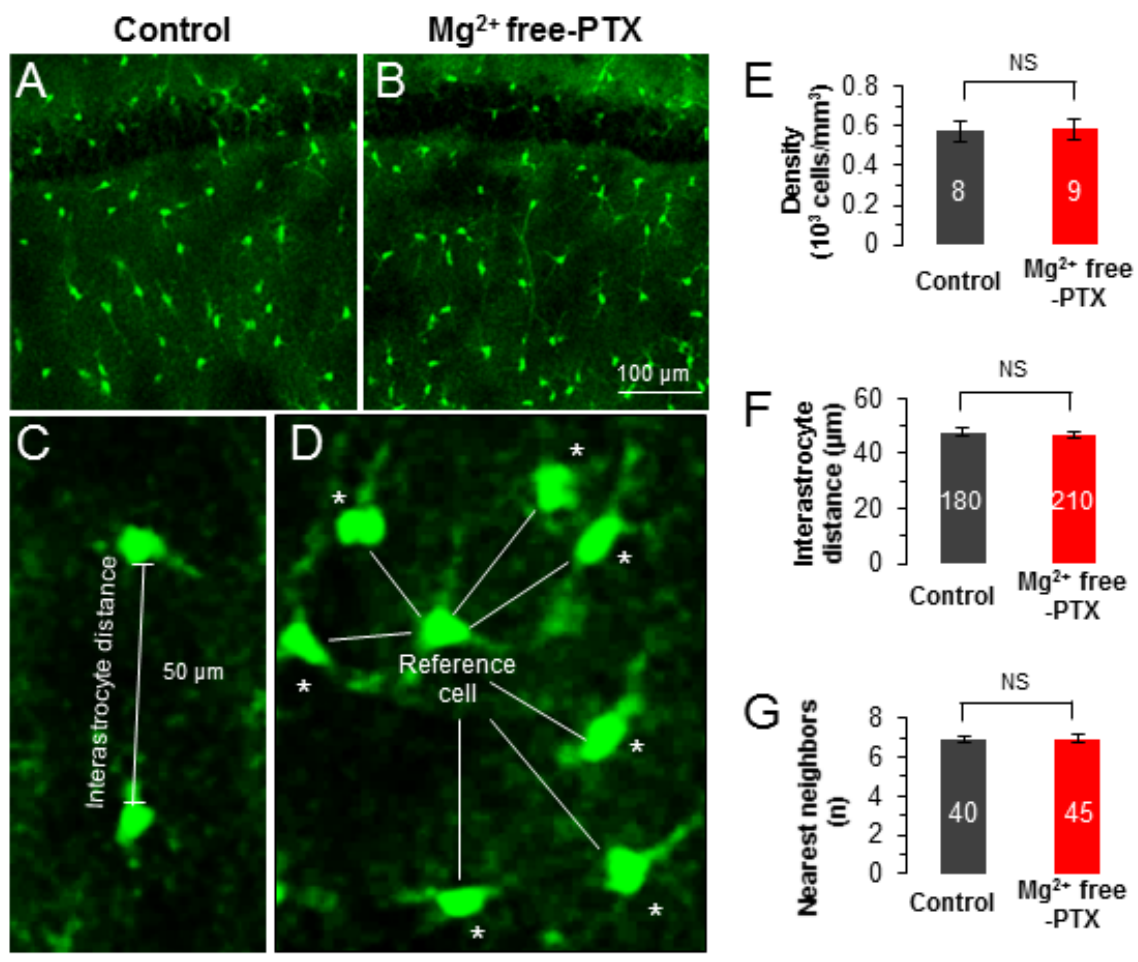

Figure 2. Acute exposure to $\mathrm{Mg}^{2+}$ free-PTX conditions does not alter the anatomy of astrocyte syncytium. $(\mathbf{A}, \mathbf{B})$ Confocal image of astrocyte networks in CA1 region from ALDH1L1-eGFP mouse of control group (A) and $\mathrm{Mg}^{2+}$ free-PTX group (B). The scale bar in (B) also applies to (A) (C,D) Representations of astrocyte syncytium anatomical parameters: interastrocyte distance and the nearest neighbors as indicated by asterisk $\left(^{*}\right)$. (E-G) Compared with the control group, no obvious differences in cell density $(E)$, interastrocyte distance $(\mathbf{F})$ and the number of nearest neighbors $(\mathbf{G})$ were observed after treatment with $\mathrm{Mg}^{2+}$ free-PTX. The numbers inside the bar graphs indicate the hemisphere brain slices in (E), the counted pair of astrocytes in (F), the counted reference cells in (G), from 3 mice in each group. NS: $p \geq 0.05$.

\section{2. $\mathrm{Mg}^{2+}$ Free-PTX Condition Depolarizes Astrocyte $V_{M}$ without Altering of Passive Conductance}

Neuronal firing elevates extracellular $\mathrm{K}^{+}$concentration $\left(\left[\mathrm{K}^{+}\right]_{\mathrm{e}}\right)$ [34-36]. After exposure to $\mathrm{Mg}^{2+}$ free-PTX solution, astrocyte $V_{\mathrm{M}}$ depolarized from $-79.9 \pm 0.9 \mathrm{mV}$ ( $n=11$ recordings from 7 mice) to $-75.5 \pm 1.1 \mathrm{mV}$ ( $n=5$ recordings from 3 mice, $p<0.05$, Figure $3 \mathrm{C}$ ). This is consistent with the notion that epileptiform neuronal activity elevates $\left[\mathrm{K}^{+}\right]_{\mathrm{e}}$.

To determine whether $\mathrm{Mg}^{2+}$ free-PTX condition also affect the functional $\mathrm{K}^{+}$channels that in turn contributed to the depolarized astrocyte $V_{\mathrm{M}}$, we used voltage-clamp recording to examine the current profile of astrocyte $\mathrm{K}^{+}$channel expression. The passive behavior of astrocyte membrane conductance is known to reflect the intrinsic properties of known and unknown $\mathrm{K}^{+}$channels, including inwardly rectifying $\mathrm{K}^{+}$channel $[28,30,37,38]$. We found that the overall passive conductance was not altered by $\mathrm{Mg}^{2+}$ free-PTX treatment (Figure 3A,B). To further examine this, we compared the rectification index (RI) between control and $\mathrm{Mg}^{2+}$ free-PTX treatment groups [39]. The RI values were comparable between control $\left(0.99 \pm 0.01, n=10\right.$ recordings from 10 mice) and $\mathrm{Mg}^{2+}$ free-PTX treatment group $(0.97$ $\pm 0.03, n=6$ recordings from 6 mice, $p>0.05$, Figure 3D). 


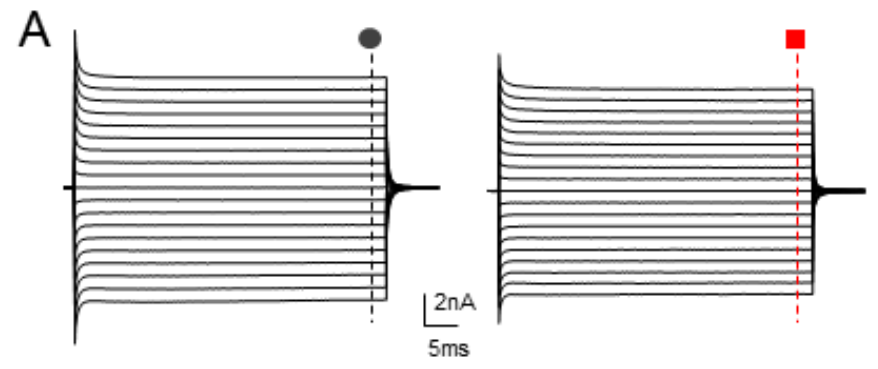

B

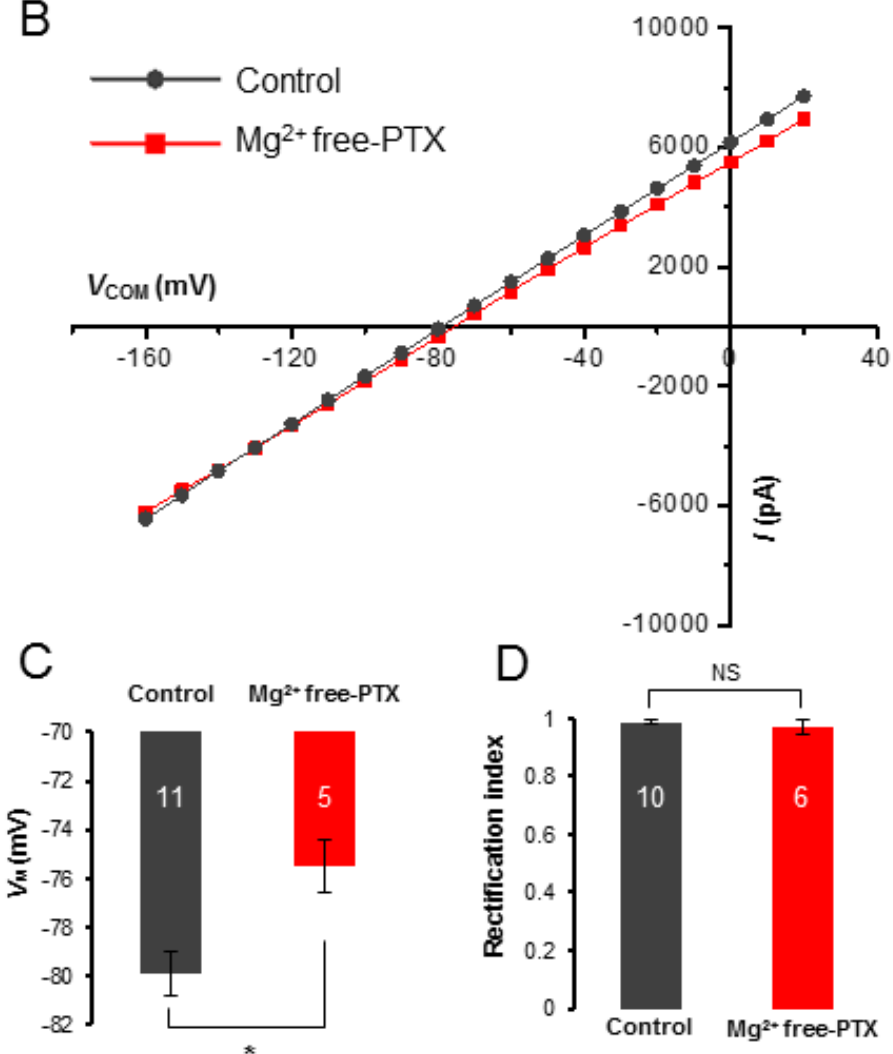

Figure 3. Epileptiform neuronal discharges do not induce changes in astrocyte passive conductance but depolarizes astrocytes. (A,B) The passive membrane conductance was not altered by $\mathrm{Mg}^{2+}$ free-PTX

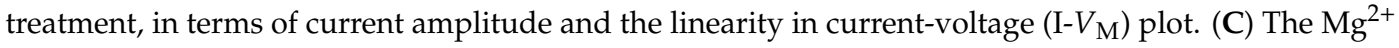
free-PTX perfusion depolarized astrocyte $V_{\mathrm{M}}$ by $4.4 \mathrm{mV}$ compared to control group in $\left[\mathrm{K}^{+}\right]_{\mathrm{p}}$ recording. (D) The rectification index (RI) values were comparable between $\mathrm{Mg}^{2+}$ free-PTX treated astrocytes and control group. *: $p<0.05$, NS: $p \geq 0.05$. In summary, the characteristic passive behavior of astrocyte membrane conductance remained unchanged after $\mathrm{Mg}^{2+}$ free-PTX treatment. Therefore, the observed $V_{\mathrm{M}}$ depolarization is likely a consequence of an elevated $\left[\mathrm{K}^{+}\right]_{\mathrm{e}}$ induced by epileptic neuronal firing, instead of change in the intrinsic property of astrocyte membrane $\mathrm{K}^{+}$channels.

\subsection{Epileptiform Neuronal Discharges Impair the Strength of Syncytial Isopotentiality}

Substitution of intracellular $\mathrm{K}^{+}$content by the $\mathrm{Na}^{+}$ions should depolarize at the recorded astrocyte to $\sim 0 \mathrm{mV}$ following to the Nernstian prediction. This indeed occurs in the single freshly dissociated astrocyte (Figure $4 \mathrm{~A}$, left) where rupture of an astrocyte by $\left[\mathrm{Na}^{+}\right]_{\mathrm{p}}$ resulted in a progressive $V_{\mathrm{M}}$ depolarization to $0 \mathrm{mV}$ (Figure 4B, green trace). Note that immediately after membrane rupture, the initial $V_{\mathrm{M}}\left(V_{\mathrm{M}, \mathrm{I}}\right)$ reflects the resting $V_{\mathrm{M}}$ of the cell, whereas the $V_{\mathrm{M}}$ at the steady-state level $\left(V_{\mathrm{M}, \mathrm{SS}}\right)$ reflects the $V_{\mathrm{M}}$ of Nernstian prediction $[13,15]$. The $V_{\mathrm{M}, \mathrm{SS}}$ is $-1.8 \pm 1.7 \mathrm{mV}$ in freshly dissociated single astrocytes ( $n=6$ recordings from five mice) (Figure $4 \mathrm{C}$, green bar). 

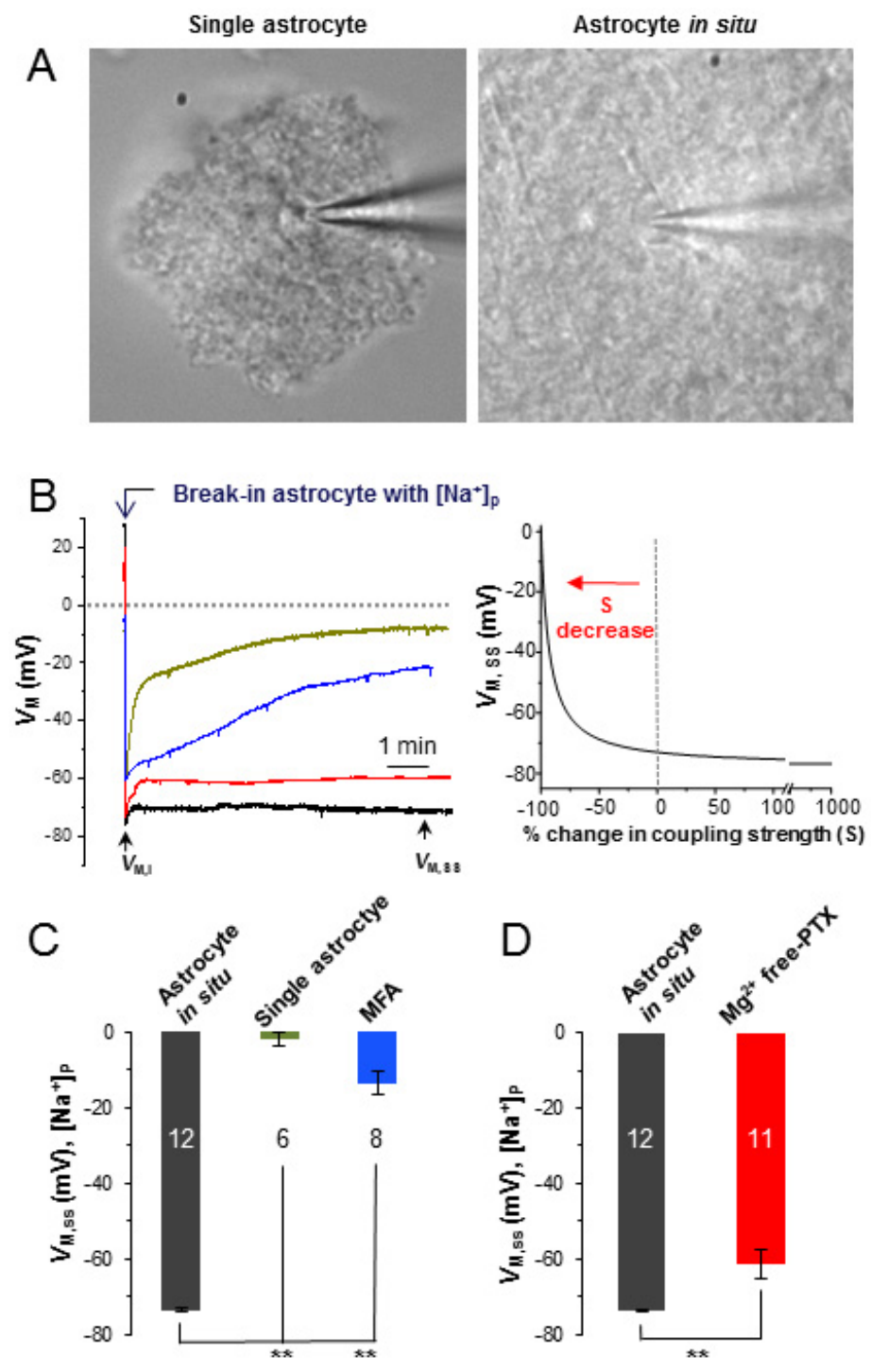

Figure 4. Epileptiform neuronal discharges impair the strength of syncytial coupling. (A) DIC images of a single freshly dissociated astrocyte (left), and an astrocyte in situ (right). (B) $V_{\mathrm{M}}$ recordings from an astrocyte in situ (black trace), a single astrocyte (green trace), an astrocyte in situ with MFA treatment (blue trace) and an astrocyte in situ with $\mathrm{Mg}^{2+}$ free-PTX treatment (red trace). On the right panel, a computational modeling illustrates an exponential relationship between the coupling strength (S) and the steady-state $V_{\mathrm{M}}\left(V_{\mathrm{M}, \mathrm{SS}}\right)$ recorded from $\left[\mathrm{Na}^{+}\right]_{\mathrm{p}}$ recording. (C) Substitution of intracellular $\mathrm{K}^{+}$ content by $\left[\mathrm{Na}^{+}\right]_{\mathrm{p}}$ resulted in depolarization of $V_{\mathrm{M}, \mathrm{SS}}$ to $-1.8 \pm 1.7 \mathrm{mV}$ in a single astrocyte following Nernstian prediction. In the presence of MFA, the $V_{\mathrm{M}, \mathrm{SS}}$ of an astrocyte in situ reached to a similar level as that of single dissociated astrocyte at $-13.5 \pm 3.1 \mathrm{mV}$. In syncytial coupled astrocytes, however,

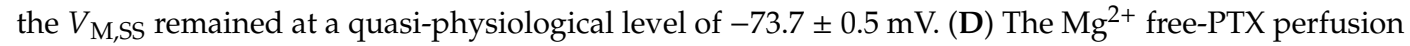
shifted the $V_{\mathrm{M}, \mathrm{SS}}$ from control level of $-73.7 \pm 0.5 \mathrm{mV}$ to $-61.3 \pm 3.7 \mathrm{mV}$. ${ }^{* *}: p<0.01$.

In a syncytial coupled astrocyte (Figure $4 \mathrm{~A}$, right), however, the $V_{\mathrm{M}, \mathrm{SS}}(-73.7 \pm 0.5 \mathrm{mV}, n=12$ recordings from five mice) remained at a quasi-physiological level due to compensation of "lost" $V_{\mathrm{M}, \mathrm{SS}}$ by the coupled syncytium (Figure $4 \mathrm{~B}$, black trace; Figure 4C,D, black bar). To further confirm this, we used a gap junction inhibitor, $100 \mu \mathrm{M}$ MFA, to block syncytial coupling [3,40].

Our previous study showed that $100 \mu \mathrm{M}$ MFA eliminates gap junction coupling by 99.3\% [13]. In the presence of MFA, the $V_{\mathrm{M}, \mathrm{SS}}(-13.5 \pm 3.1 \mathrm{mV}, n=8$ recordings from six mice), to a great extent recaptured the $V_{\mathrm{M}, \mathrm{SS}}$ level showed in single isolated astrocytes (Figure $4 \mathrm{~B}$, blue trace, Figure $4 \mathrm{C}$, blue bar). 
After $\mathrm{Mg}^{2+}$ free-PTX perfusion, the $V_{\mathrm{M}, \mathrm{SS}}$ positively shifted to $-61.3 \pm 3.7$ ( $n=11$ recordings from eight mice, Figure 4B, red trace; Figure $4 \mathrm{D}$, red bar) compared to the control group of $-73.7 \pm 0.5 \mathrm{mV}$ $(n=12)(p<0.01)$. According to our computational model prediction, this positive shift of $V_{\mathrm{M}, \mathrm{SS}}$ corresponds to a near-complete inhibition of the strength of syncytial coupling at $90 \%$ [15]. However, in $\left[\mathrm{K}^{+}\right]_{\mathrm{P}}$ recording, $\mathrm{Mg}^{2+}$ free-PTX treatment also depolarized astrocytes by $4.4 \mathrm{mV}$ (Figure 3C), mostly caused by neuronal firing induced high $\left[\mathrm{K}^{+}\right]_{\mathrm{e}}$. Taking this into consideration in our computational modeling, the $\mathrm{Mg}^{2+}$ free-PTX induced inhibition of syncytial coupling is estimated to be $84 \%$. Therefore, the epileptiform discharges severely impairs the strength of astrocyte syncytial isopotentiality.

\subsection{Epileptiform Discharges in Slices Impair the $K^{+}$Redistribution Capacity of an Astrocyte Syncytium}

The clearance of $\mathrm{K}^{+}$released from active neurons is a major function of astrocytes. In the $\mathrm{K}^{+}$ spatial buffering hypothesis, $\mathrm{K}^{+}$ions uptaken from a local area need to be spatially transferred across gap junctions and, in turn, be released to regions with less neuronal activity [41,42]. Therefore, a strong $\mathrm{K}^{+}$redistribution capacity is required. A severely reduced syncytial coupling implies an impaired spatial redistribution capacity for $\mathrm{K}^{+}$due to the insult of $\mathrm{Mg}^{2+}$ free-PTX treatment. To test this, we used $\left[\mathrm{Na}^{+}\right]_{\mathrm{p}}$ to create a "K $\mathrm{K}^{+}$-deficient astrocyte" as a "reporter" for the increase of $\left[\mathrm{K}^{+}\right]_{\mathrm{i}}$ in the recorded cell. As shown in Figure 5A,B, from a single isolated astrocyte an uptake driving force is created by using of $-2 \mathrm{nA}$ current steps at varied duration from 1-6 s. A step duration-dependent increase in $\left[\mathrm{K}^{+}\right]_{\mathrm{i}}$ is indicated by the negative shift in $V_{\text {rev }}$ values at the end of the steps, and the net accumulation of $\left[\mathrm{K}^{+}\right]_{\mathrm{i}}$ can be calculated from these $V_{\text {rev }}$ values according to Goldman-Hodgkin-Katz (GHK) equation [25,28]. In the GHK equation calculation, the $P_{\mathrm{Na}} / P_{\mathrm{K}}$ and $P_{\mathrm{Cl}} / P_{\mathrm{K}}$ and $P_{\mathrm{Ca}} / P_{\mathrm{K}}$ were assumed at $0.015,0.0$ and 0.0 , respectively $[5,26]$. As the step duration increased from 1 to 6 seconds, there was an incremental increase in $\left[\mathrm{K}^{+}\right]_{\mathrm{i}}: 13.9 \pm 4.7 \mathrm{mM}(1 \mathrm{~s}), 18.3 \pm 6.9 \mathrm{mM}(2 \mathrm{~s}), 21.2 \pm 8.0 \mathrm{mM}(3 \mathrm{~s}), 22.3 \pm 8.2 \mathrm{mM}(4 \mathrm{~s})$, $23.0 \pm 8.5 \mathrm{mM}(5 \mathrm{~s})$ and $23.2 \pm 8.5 \mathrm{mM}(6 \mathrm{~s})(n=3$ recordings from three mice, Figure $5 \mathrm{~B})$.

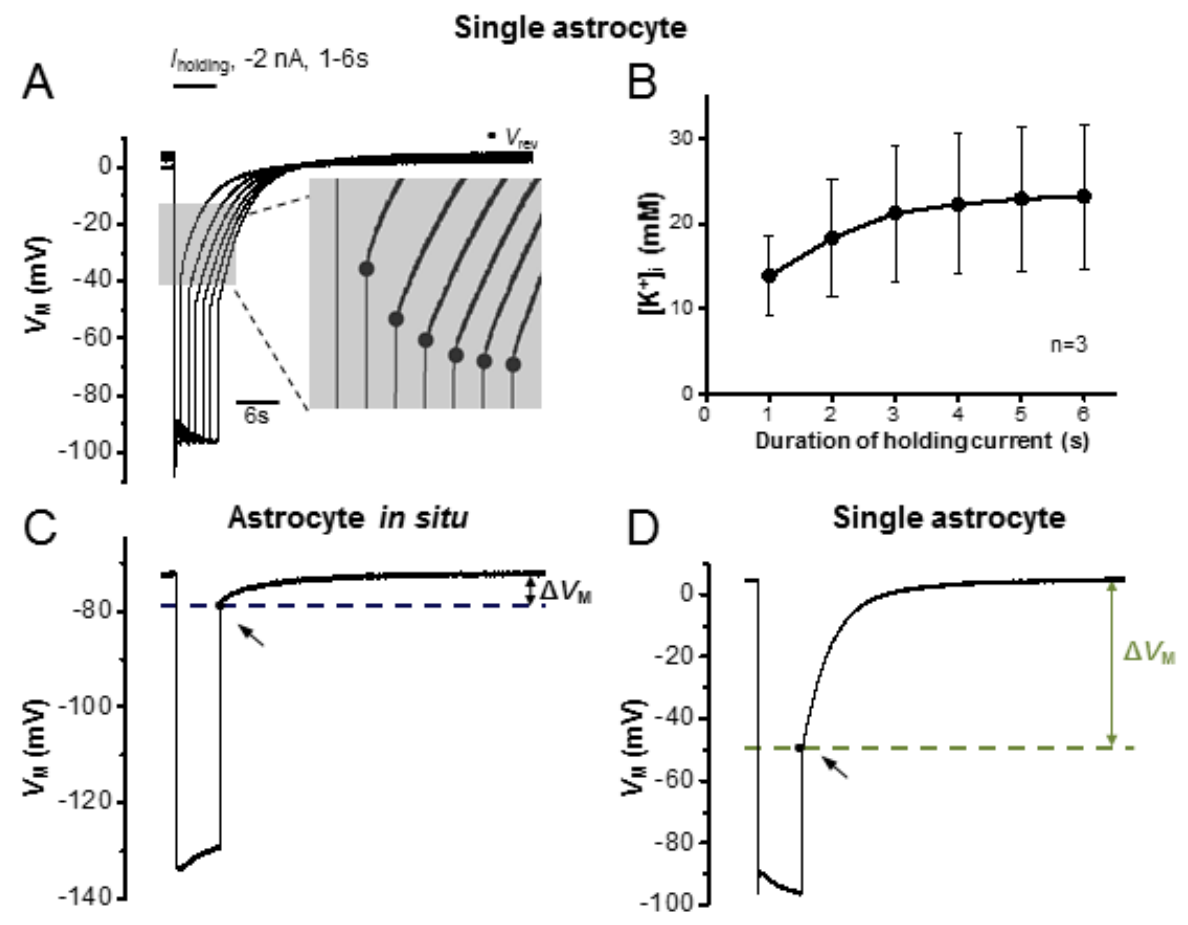

Figure 5. Cont. 

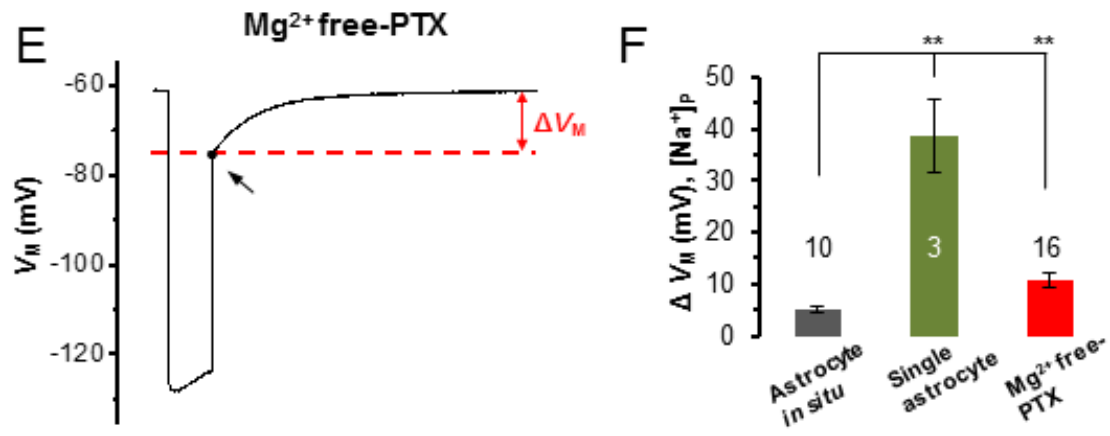

Figure 5. Epileptiform neuronal discharges impair the capacity of a syncytium for $\mathrm{K}^{+}$redistribution. (A) Single astrocyte recorded with a $\left[\mathrm{Na}^{+}\right]_{\mathrm{p}}$ in current-clamp mode; $-2 \mathrm{nA}$ current steps $\left(I_{\text {holding }}\right)$ were applied at incremental durations from 1 to $6 \mathrm{~s}$. In between these steps, the cell was maintained at resting condition for $V_{\mathrm{M}}$ recovery. The longer the duration of the current steps, the stronger the negative shift in the reversal potential $\left(V_{\text {rev }}\right)$ upon withdrawal of the steps, indicating more accumulation of $\mathrm{K}^{+}$inside astrocytes. (B) Based on the $V_{\text {rev }}$ values recorded in single astrocytes, the $\left[\mathrm{K}^{+}\right]_{\mathrm{i}}$ values were calculated according to the Goldman-Hodgkin-Katz equation, and are plotted against the step pulse durations. (C-E) In $\left[\mathrm{Na}^{+}\right]_{p}$ recording, the $\Delta V_{\mathrm{M}}$ is the difference between the basal $V_{\mathrm{M}}$ and $V_{\text {rev }}$ values, and is used to compare the capacity of $\mathrm{K}^{+}$redistribution under indicated conditions. Representative recordings of $\Delta V_{\mathrm{M}}$ from an astrocyte in situ (C), a single astrocyte (D) and an astrocyte with $\mathrm{Mg}^{2+}$ free-PTX treatment (E). (F) Comparison of $\Delta V_{\mathrm{M}}$ between astrocytes in situ with single astrocytes, and with astrocytes after treating with $\mathrm{Mg}^{2+}$ free-PTX, a significant change occurred to both comparisons, indicating $\mathrm{Mg}^{2+}$ free-PTX treatment significantly impairs the redistribution capacity of an astrocyte syncytium. ${ }^{* *}: p<0.01$.

In a syncytial coupled astrocyte, the $V_{\text {rev }}$ is not only affected by the negative holding current but also altered by syncytial isopotentiality. Therefore, only the relative change in $V_{\text {rev }}\left(\Delta V_{\mathrm{M}}\right)$ can be used for comparison of $\mathrm{K}^{+}$redistribution capacity, while the intracellular $\mathrm{K}^{+}$contents calculation is not feasible in this condition. As shown in Figure 5C, in syncytial coupled astrocytes, only a minor $\Delta V_{\mathrm{M}}$ occurred in response to a $6 \mathrm{~s}$ step, $5.08 \pm 0.45 \mathrm{mV}(n=10$ recordings from three mice). In the group treated with $\mathrm{Mg}^{2+}$ free-PTX, the inhibition of syncytial coupling is indicated by a larger $\Delta V_{\mathrm{M}}, 10.74 \pm 1.55 \mathrm{mV}$ ( $n=16$ recordings from seven mice, Figure $\left.5 \mathrm{E}\right)$, compared to astrocyte in situ $(p<0.01$, Figure $5 \mathrm{~F})$. For comparison, the largest $\Delta V_{\mathrm{M}}$ was induced from single isolated astrocytes, $38.62 \pm 7.02 \mathrm{mV}\left(n=3\right.$ recordings from three mice, Figure 5D). Altogether, we show that the $\mathrm{Mg}^{2+}$ free-PTX treatment severely impairs the $\mathrm{K}^{+}$redistribution capacity in astrocyte syncytium.

\section{Discussion}

Despite decades of investigation, the impact of seizure activity on astrocyte gap junction coupling remains controversial. A seizure-induced increase, decrease or unaltered expression of gap junction channels, connexin 43 and 30, have all been reported at both the transcript and protein levels in human epilepsy and in animal epilepsy models [43,44].

At the functional levels, the results were also contradictory. In a genetic mouse model of tuberous sclerosis complex, a human disease associated with medically intractable seizures, a significant reduction of inter-astrocytic dye coupling has been reported in the hippocampal CA1 region [45]. On the contrary, an increase in astrocyte dye coupling has been reported in a rat model of temporal lobe epilepsy (systemic kainate injection) during the latent 7-16 days post status epilepticus [46]. An increased coupling has also been found in fluorescence recovery measurement after photobleaching (FRAP) in hippocampal slice cultures after chronic exposure to $\mathrm{GABA}_{\mathrm{A}}$ receptor inhibitor bicuculline, which developed a chronic in vitro model of epilepsy [47]. 


\subsection{Epileptiform Neuronal Discharges Impair Astrocyte Gap Junction Coupling}

To address this controversial and important question, a common $\mathrm{Mg}^{2+}$ free-PTX model was used to induce epileptiform discharges in hippocampal slices. In the present study, we intended to examine the acute effect of $\mathrm{Mg}^{2+}$ free-PTX treatment on the anatomy and function of the astrocyte syncytium. The epileptiform discharges could be readily induced (Figure 1). Importantly, within this relatively short time window, neither the cellular morphology nor the spatial organization pattern of astrocytes was noticeably altered. Therefore, this model allowed us to examine the acute impact of epileptiform discharges on astrocyte syncytial coupling strength.

The acute functional impact of epileptiform discharges on syncytial isopotentiality has been explored with a new electrophysiological method recently developed by us [23]. Using this method, we show that epileptic neuronal activity weakens the syncytial coupling; this is indicated by a positive shift of the steady-state quasi-physiological $V_{\mathrm{M}}\left(V_{\mathrm{M}, \mathrm{SS}}\right)$ (Figure 4$)$. A $12.4 \mathrm{mV}$ positive shift in $V_{\mathrm{M}, \mathrm{SS}}$ corresponds to a $90 \%$ inhibition of astrocyte syncytial coupling [15].

The basal level of astrocyte $V_{\mathrm{M}}$ fluctuates minimally following the change of $\left[\mathrm{K}^{+}\right]_{\mathrm{e}}$ in vivo [48-50]. Intensive neuronal activity, however, can increase $\left[\mathrm{K}^{+}\right]_{\mathrm{e}}$ to a ceiling level of $12 \mathrm{mM}$ in active neuronal zones. In our studies, $\mathrm{Mg}^{2+}$ free-PTX treatment induced a $4.4 \mathrm{mV} V_{\mathrm{M}}$ depolarization, whereas the passive conductance remained intact (Figure 3 ). These results indicate that elevation of $\left[\mathrm{K}^{+}\right]_{\mathrm{e}}$ should be mostly accountable for $\mathrm{Mg}^{2+}$ free-PTX treatment induced astrocyte $V_{\mathrm{M}}$ depolarization.

It should be noted that in $\left[\mathrm{Na}^{+}\right]_{\mathrm{p}}$ recording, part of the positive shift of $V_{\mathrm{M}, \mathrm{SS}}(12.4 \mathrm{mV})$ could also be attributable to $\left[\mathrm{K}^{+}\right]_{\mathrm{e}}$ increase. Nevertheless, after correction of this portion of $V_{\mathrm{M}}$ depolarization, the $\mathrm{Mg}^{2+}$ free-PTX treatment induced syncytial coupling inhibition still reaches $\sim 84 \%$ based on our model prediction $[15,23]$.

\subsection{Epileptiform Discharges Impair the Redistribution Capacity of a Syncytium for $\mathrm{K}^{+}$Ions}

The weakening of syncytial coupling should affect the redistribution capacity of a syncytium for $\mathrm{K}^{+}$ions. Assuming $\mathrm{K}^{+}$spatial buffering does serve as a critical homeostatic mechanism, a significant closure of network coupling should severely affect the $\mathrm{K}^{+}$homeostasis in the brain. In the present study, this possibility has been tested by comparison of the $\mathrm{K}^{+}$redistribution capacity from a syncytial coupled astrocyte after the experimental accumulation of intracellular $\mathrm{K}^{+}$ions. We found that indeed weakened syncytial coupling significantly attenuated the ability of astrocytes to redistribute experimentally accumulated $\mathrm{K}^{+}$ions to the coupled syncytium after treating the slices with $\mathrm{Mg}^{2+}$ free-PTX.

\subsection{Acute vs Chronic Impact of Epileptiform Discharges on Astrocyte Syncytium}

Epilepsy is often accompanied by massive reactive gliosis in patients [51]. This observation has also been simulated in animal models of epilepsy [52]. Astrogliosis disrupts the mutually exclusive astrocytic domains that lead to an extensive interdigitation of astrocyte processes. It has been speculated that this pathological change may enhance astrocyte-astrocyte contact and hence a stronger coupling [46]. However, another report has shown the lack of dye coupling among proliferating reactive astrocytes [53].

In the present study, we asked if epileptiform discharges could exert acute alterations to the structure of individual astrocytes as well as their established syncytium. Our results show that after short-term exposure to epileptic insults, no obvious change was induced in astrocyte morphology in terms of hypertrophy. Also, astrocyte cell density and the pattern of spatial organization were not altered by $\mathrm{Mg}^{2+}$ free-PTX treatment. These results indicate that the functional state of a syncytium could be altered way ahead of the pathological manifestation in the morphology of individual astrocyte and astrocyte syncytium.

Although the underlying mechanisms are yet to be identified, several regulatory mechanisms of gap junction coupling and syncytial isopotentiality could be initiated by neuronal activity. First, the control ability of syncytial isopotentiality weakens with expanding high $\mathrm{K}^{+}$affected areas inside a 
syncytium. Second, the coupling strength $(s)$ weakens when membrane $K^{+}$conductance $\left(\mathrm{G}_{\mathrm{K}}\right)$ increases under a constant gap junction conductance $\left(\mathrm{G}_{\mathrm{g}}\right)\left(s=\mathrm{G}_{\mathrm{g}} / \mathrm{G}_{\mathrm{K}}\right)$ [13]. In regions experiencing intensive neuronal activity, a high $\mathrm{K}^{+}$influx rate in astrocytes, or increased $\mathrm{G}_{\mathrm{K}}$, is inevitable as prediction by Goldman-Hodgkin-Katz (GHK) current equation [54]. This can, in turn, lead to a weakening coupling strength. Thus, disruption of syncytial isopotentiality is expected during intensive neuronal activity. Third, it is well-established that glutamatergic signaling induces intracellular $\mathrm{Ca}^{2+}$ elevation

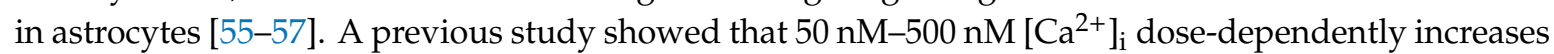
the open probability of $\mathrm{Cx} 43$, whereas further increase in $\left[\mathrm{Ca}^{2+}\right]_{i}$ from $500 \mathrm{nM}$ to $1 \mathrm{mM}$ progressively inhibits Cx43 [58]. Because of the complexity, further experiments are necessary to uncover in detail the dynamic interactive mechanism between a syncytium and its associated neuronal networks.

The role of astrocytes in epilepsy has attracted increasing research attention, therefore it is possible that the future anti-epileptic therapies may target specifically on astrocytes. In the present study, our study provides the first evidence that the dysfunction of syncytium indeed contributes to the pathology of epilepsy; therefore, gap junction coupling could be a promising target for the development of future antiepileptic treatment.

\section{Conclusions}

Our anatomical and electrophysiological studies show that despite no change in the gross anatomy of astrocyte syncytium, a short-term bout of epileptiform neuronal discharge is sufficient to weaken the strength of syncytial coupling and impair the capacity of a syncytium for spatial redistribution of $\mathrm{K}^{+}$ions.

Author Contributions: Q.W., Y.D. and M.Z.: project conception and design. Q.W., W.W., S.A., C.M.K., Y.D.: data collection, data analysis, and interpretation. Q.W., Y.D., and M.Z.: manuscript writing. All authors corrected and approved the manuscript.

Funding: This work is sponsored by grants from National Institute of Neurological Disorders and Stroke RO1NS062784, R56NS097972, RO1NS116059 (MZ). A NRI Pilot Award from, Ohio State University Wexner Medical Center (MZ).

Conflicts of Interest: The authors declare no conflict of interest.

\section{References}

1. Binmoller, F.J.; Muller, C.M. Postnatal development of dye-coupling among astrocytes in rat visual cortex. Glia 1992, 6, 127-137. [CrossRef] [PubMed]

2. Gutnick, M.J.; Connors, B.W.; Ransom, B.R. Dye-coupling between glial cells in the guinea pig neocortical slice. Brain Res. 1981, 213, 486-492. [CrossRef]

3. Xu, G.; Wang, W.; Kimelberg, H.K.; Zhou, M. Electrical coupling of astrocytes in rat hippocampal slices under physiological and simulated ischemic conditions. Glia 2010, 58, 481-493. [CrossRef] [PubMed]

4. Kuga, N.; Sasaki, T.; Takahara, Y.; Matsuki, N.; Ikegaya, Y. Large-scale calcium waves traveling through astrocytic networks in vivo. J. Neurosci. 2011, 31, 2607-2614. [CrossRef] [PubMed]

5. Langer, J.; Stephan, J.; Theis, M.; Rose, C.R. Gap junctions mediate intercellular spread of sodium between hippocampal astrocytes in situ. Glia 2012, 60, 239-252. [CrossRef] [PubMed]

6. Rouach, N.; Koulakoff, A.; Abudara, V.; Willecke, K.; Giaume, C. Astroglial metabolic networks sustain hippocampal synaptic transmission. Science 2008, 322, 1551-1555. [CrossRef]

7. Newman, E.A. Propagation of intercellular calcium waves in retinal astrocytes and Muller cells. J. Neurosci. 2001, 21, 2215-2223. [CrossRef]

8. Bellot-Saez, A.; Cohen, G.; van Schaik, A.; Ooi, L.; Morley, J.W.; Buskila, Y. Astrocytic modulation of cortical oscillations. Sci. Rep. 2018, 8, 11565. [CrossRef]

9. Lutz, S.E.; Zhao, Y.; Gulinello, M.; Lee, S.C.; Raine, C.S.; Brosnan, C.F. Deletion of astrocyte connexins 43 and 30 leads to a dysmyelinating phenotype and hippocampal CA1 vacuolation. J. Neurosci. 2009, 29, 7743-7752. [CrossRef]

10. Pannasch, U.; Vargova, L.; Reingruber, J.; Ezan, P.; Holcman, D.; Giaume, C.; Sykova, E.; Rouach, N. Astroglial networks scale synaptic activity and plasticity. Proc. Natl. Acad. Sci. USA 2011, 108, 8467-8472. [CrossRef] 
11. Theis, M.; Jauch, R.; Zhuo, L.; Speidel, D.; Wallraff, A.; Doring, B.; Frisch, C.; Sohl, G.; Teubner, B.; Euwens, C.; et al. Accelerated hippocampal spreading depression and enhanced locomotory activity in mice with astrocyte-directed inactivation of connexin43. J. Neurosci. 2003, 23, 766-776. [CrossRef] [PubMed]

12. Wallraff, A.; Kohling, R.; Heinemann, U.; Theis, M.; Willecke, K.; Steinhauser, C. The impact of astrocytic gap junctional coupling on potassium buffering in the hippocampus. J. Neurosci. 2006, 26, 5438-5447. [CrossRef] [PubMed]

13. Ma, B.; Buckalew, R.; Du, Y.; Kiyoshi, C.M.; Alford, C.C.; Wang, W.; McTigue, D.M.; Enyeart, J.J.; Terman, D.; Zhou, M. Gap junction coupling confers isopotentiality on astrocyte syncytium. Glia 2016, 64, 214-226. [CrossRef] [PubMed]

14. Huang, M.; Du, Y.; Kiyoshi, C.M.; Wu, X.; Askwith, C.C.; McTigue, D.M.; Zhou, M. Syncytial Isopotentiality: An Electrical Feature of Spinal Cord Astrocyte Networks. Neuroglia 2018, 1, 271-279. [CrossRef]

15. Kiyoshi, C.M.; Du, Y.; Zhong, S.; Wang, W.; Taylor, A.T.; Xiong, B.; Ma, B.; Terman, D.; Zhou, M. Syncytial isopotentiality: A system-wide electrical feature of astrocytic networks in the brain. Glia 2018, 66, 2756-2769. [CrossRef]

16. Kiyoshi, C.M.; Zhou, M. Astrocyte syncytium: A functional reticular system in the brain. Neural Regen. Res. 2019, 14, 595-596. [CrossRef]

17. Samoilova, M.; Wentlandt, K.; Adamchik, Y.; Velumian, A.A.; Carlen, P.L. Connexin 43 mimetic peptides inhibit spontaneous epileptiform activity in organotypic hippocampal slice cultures. Exp. Neurol. 2008, 210, 762-775. [CrossRef]

18. Steinhauser, C.; Seifert, G. Glial membrane channels and receptors in epilepsy: Impact for generation and spread of seizure activity. Eur. J. Pharm. 2002, 447, 227-237. [CrossRef]

19. Fiacco, T.A.; Agulhon, C.; McCarthy, K.D. Sorting out astrocyte physiology from pharmacology. Annu. Rev. Pharmacol. Toxicol. 2009, 49, 151-174. [CrossRef]

20. Halassa, M.M.; Fellin, T.; Haydon, P.G. Tripartite synapses: Roles for astrocytic purines in the control of synaptic physiology and behavior. Neuropharmacology 2009, 57, 343-346. [CrossRef]

21. Bennett, M.V.; Barrio, L.C.; Bargiello, T.A.; Spray, D.C.; Hertzberg, E.; Saez, J.C. Gap junctions: New tools, new answers, new questions. Neuron 1991, 6, 305-320. [CrossRef]

22. Christ, G.J.; Moreno, A.P.; Melman, A.; Spray, D.C. Gap junction-mediated intercellular diffusion of Ca2+ in cultured human corporal smooth muscle cells. Am. J. Physiol. 1992, 263, C373-C383. [CrossRef] [PubMed]

23. Du, Y.; Kiyoshi, C.M.; Terman, D.; Zhou, M. Analysis of the functional states of an astrocyte syncytium. In Basic Neurobiology Techniques; Wright, N., Ed.; Humana: New York, NY, USA, 2020; Volume 152, pp. $285-313$.

24. Yang, Y.; Vidensky, S.; Jin, L.; Jie, C.; Lorenzini, I.; Frankl, M.; Rothstein, J.D. Molecular comparison of GLT1+ and ALDH1L1+ astrocytes in vivo in astroglial reporter mice. Glia 2011, 59, 200-207. [CrossRef] [PubMed]

25. Zhong, S.; Du, Y.; Kiyoshi, C.M.; Ma, B.; Alford, C.C.; Wang, Q.; Yang, Y.; Liu, X.; Zhou, M. Electrophysiological behavior of neonatal astrocytes in hippocampal stratum radiatum. Mol. Brain 2016, 9, 34. [CrossRef]

26. Ma, B.F.; Xie, M.J.; Zhou, M. Bicarbonate efflux via GABA(A) receptors depolarizes membrane potential and inhibits two-pore domain potassium channels of astrocytes in rat hippocampal slices. Glia 2012, 60, 1761-1772. [CrossRef]

27. Nimmerjahn, A.; Kirchhoff, F.; Kerr, J.N.; Helmchen, F. Sulforhodamine 101 as a specific marker of astroglia in the neocortex in vivo. Nat. Methods 2004, 1, 31-37. [CrossRef]

28. Du, Y.; Ma, B.; Kiyoshi, C.M.; Alford, C.C.; Wang, W.; Zhou, M. Freshly dissociated mature hippocampal astrocytes exhibit passive membrane conductance and low membrane resistance similarly to syncytial coupled astrocytes. J. Neurophysiol. 2015, 113, 3744-3750. [CrossRef]

29. Du, Y.; Wang, W.; Lutton, A.D.; Kiyoshi, C.M.; Ma, B.; Taylor, A.T.; Olesik, J.W.; McTigue, D.M.; Askwith, C.C.; Zhou, M. Dissipation of transmembrane potassium gradient is the main cause of cerebral ischemia-induced depolarization in astrocytes and neurons. Exp. Neurol. 2018, 303, 1-11. [CrossRef]

30. Ma, B.; Xu, G.; Wang, W.; Enyeart, J.J.; Zhou, M. Dual patch voltage clamp study of low membrane resistance astrocytes in situ. Mol. Brain 2014, 7, 18. [CrossRef]

31. Zhang, H.; Xie, M.; Schools, G.P.; Feustel, P.F.; Wang, W.; Lei, T.; Kimelberg, H.K.; Zhou, M. Tamoxifen mediated estrogen receptor activation protects against early impairment of hippocampal neuron excitability in an oxygen/glucose deprivation brain slice ischemia model. Brain Res. 2009, 1247, 196-211. [CrossRef] 
32. Wang, W.; Kiyoshi, C.M.; Du, Y.; Taylor, A.T.; Sheehan, E.R.; Wu, X.; Zhou, M. TREK-1 Null Impairs Neuronal Excitability, Synaptic Plasticity, and Cognitive Function. Mol. Neurobiol. 2020, 57, 1332-1346. [CrossRef] [PubMed]

33. Chever, O.; Dossi, E.; Pannasch, U.; Derangeon, M.; Rouach, N. Astroglial networks promote neuronal coordination. Sci. Signal. 2016, 9, ra6. [CrossRef] [PubMed]

34. Baylor, D.A.; Nicholls, J.G. Changes in extracellular potassium concentration produced by neuronal activity in the central nervous system of the leech. J. Physiol. 1969, 203, 555-569. [CrossRef] [PubMed]

35. Heinemann, U.; Lux, H.D. Ceiling of stimulus induced rises in extracellular potassium concentration in the cerebral cortex of cat. Brain Res. 1977, 120, 231-249. [CrossRef]

36. Frankenhaeuser, B.; Hodgkin, A.L. The after-effects of impulses in the giant nerve fibres of Loligo. J. Physiol. 1956, 131, 341-376. [CrossRef]

37. Zhou, M.; Kimelberg, H.K. Freshly isolated astrocytes from rat hippocampus show two distinct current patterns and different $[\mathrm{K}(+)](\mathrm{o})$ uptake capabilities. J. Neurophysiol. 2000, 84, 2746-2757. [CrossRef]

38. Du, Y.; Kiyoshi, C.M.; Wang, Q.; Wang, W.; Ma, B.; Alford, C.C.; Zhong, S.; Wan, Q.; Chen, H.; Lloyd, E.E.; et al. Genetic Deletion of TREK-1 or TWIK-1/TREK-1 Potassium Channels does not Alter the Basic Electrophysiological Properties of Mature Hippocampal Astrocytes In Situ. Front. Cell. Neurosci. 2016, 10, 13. [CrossRef]

39. Wang, W.; Kiyoshi, C.M.; Du, Y.; Ma, B.; Alford, C.C.; Chen, H.; Zhou, M. mGluR3 Activation Recruits Cytoplasmic TWIK-1 Channels to Membrane that Enhances Ammonium Uptake in Hippocampal Astrocytes. Mol. Neurobiol. 2016, 53, 6169-6182. [CrossRef]

40. Xu, G.; Wang, W.; Zhou, M. Spatial organization of NG2 glial cells and astrocytes in rat hippocampal CA1 region. Hippocampus 2014, 24, 383-395. [CrossRef]

41. Orkand, R.K.; Nicholls, J.G.; Kuffler, S.W. Effect of nerve impulses on the membrane potential of glial cells in the central nervous system of amphibia. J. Neurophysiol. 1966, 29, 788-806. [CrossRef]

42. Kofuji, P.; Newman, E.A. Potassium buffering in the central nervous system. Neuroscience 2004, 129, 1045-1056. [CrossRef] [PubMed]

43. Giaume, C.; Koulakoff, A.; Roux, L.; Holcman, D.; Rouach, N. Astroglial networks: A step further in neuroglial and gliovascular interactions. Nat. Rev. Neurosci. 2010, 11, 87-99. [CrossRef] [PubMed]

44. Steinhauser, C.; Seifert, G.; Bedner, P. Astrocyte dysfunction in temporal lobe epilepsy: K+ channels and gap junction coupling. Glia 2012, 60, 1192-1202. [CrossRef] [PubMed]

45. Xu, L.; Zeng, L.H.; Wong, M. Impaired astrocytic gap junction coupling and potassium buffering in a mouse model of tuberous sclerosis complex. Neurobiol. Dis. 2009, 34, 291-299. [CrossRef] [PubMed]

46. Takahashi, D.K.; Vargas, J.R.; Wilcox, K.S. Increased coupling and altered glutamate transport currents in astrocytes following kainic-acid-induced status epilepticus. Neurobiol. Dis. 2010, 40, 573-585. [CrossRef] [PubMed]

47. Samoilova, M.; Li, J.; Pelletier, M.R.; Wentlandt, K.; Adamchik, Y.; Naus, C.C.; Carlen, P.L. Epileptiform activity in hippocampal slice cultures exposed chronically to bicuculline: Increased gap junctional function and expression. J. Neurochem. 2003, 86, 687-699. [CrossRef]

48. Mishima, T.; Hirase, H. In vivo intracellular recording suggests that gray matter astrocytes in mature cerebral cortex and hippocampus are electrophysiologically homogeneous. J. Neurosci. 2010, 30, 3093-3100. [CrossRef]

49. Amzica, F.; Massimini, M. Glial and neuronal interactions during slow wave and paroxysmal activities in the neocortex. Cereb. Cortex 2002, 12, 1101-1113. [CrossRef]

50. Amzica, F.; Massimini, M.; Manfridi, A. Spatial buffering during slow and paroxysmal sleep oscillations in cortical networks of glial cells in vivo. J. Neurosci. 2002, 22, 1042-1053. [CrossRef]

51. McKhann, G.M., 2nd; Schoenfeld-McNeill, J.; Born, D.E.; Haglund, M.M.; Ojemann, G.A. Intraoperative hippocampal electrocorticography to predict the extent of hippocampal resection in temporal lobe epilepsy surgery. J. Neurosurg. 2000, 93, 44-52. [CrossRef]

52. Oberheim, N.A.; Tian, G.F.; Han, X.; Peng, W.; Takano, T.; Ransom, B.; Nedergaard, M. Loss of astrocytic domain organization in the epileptic brain. J. Neurosci. 2008, 28, 3264-3276. [CrossRef] [PubMed]

53. Bordey, A.; Lyons, S.A.; Hablitz, J.J.; Sontheimer, H. Electrophysiological characteristics of reactive astrocytes in experimental cortical dysplasia. J. Neurophysiol. 2001, 85, 1719-1731. [CrossRef] [PubMed]

54. Hille, B. Ion Channels of Excitable Cells; Sinauer: Sunderland, MA, USA, 2001. 
55. Nimmerjahn, A.; Mukamel, E.A.; Schnitzer, M.J. Motor behavior activates Bergmann glial networks. Neuron 2009, 62, 400-412. [CrossRef] [PubMed]

56. Panatier, A.; Vallee, J.; Haber, M.; Murai, K.K.; Lacaille, J.C.; Robitaille, R. Astrocytes are endogenous regulators of basal transmission at central synapses. Cell 2011, 146, 785-798. [CrossRef] [PubMed]

57. Schummers, J.; Yu, H.; Sur, M. Tuned responses of astrocytes and their influence on hemodynamic signals in the visual cortex. Science 2008, 320, 1638-1643. [CrossRef]

58. Wang, N.; De Bock, M.; Antoons, G.; Gadicherla, A.K.; Bol, M.; Decrock, E.; Evans, W.H.; Sipido, K.R.; Bukauskas, F.F.; Leybaert, L. Connexin mimetic peptides inhibit Cx43 hemichannel opening triggered by voltage and intracellular Ca2+ elevation. Basic Res. Cardiol. 2012, 107, 304. [CrossRef]

(C) 2020 by the authors. Licensee MDPI, Basel, Switzerland. This article is an open access article distributed under the terms and conditions of the Creative Commons Attribution (CC BY) license (http://creativecommons.org/licenses/by/4.0/). 